九州大学学術情報リポジトリ

Kyushu University Institutional Repository

\title{
Skull Growth and Variation in the Formosan Wood Mouse, Apodemus semotus
}

Lin, Liang-Kong

Zoological Laboratory, Faculty of Agriculture, Kyushu University

Shiraishi, Satoshi

Zoological Laboratory, Faculty of Agriculture, Kyushu University

https://doi.org/10.5109/23997

出版情報：九州大学大学院農学研究院紀要. 37 (1)，pp.51-69，1992-12. Kyushu University バージョン：

権利関係 : 


\title{
Skull Growth and Variation in the Formosan W ood M ouse, Apodemus semotus*
}

\author{
Liang-K ong Lin and Satoshi Shiraishi \\ Zoological Laboratory, Faculty of Agriculture, \\ Kyushu University 46-06, Fukuoka 812, Japan
}

(Received May 15, 1992)

\begin{abstract}
The skull growth and variation of Apodemus semotus were investigated using laboratory and field specimens. Among 15 skull characters, the largest and second largest growth rates on days O-24 were for the nasal length. On days 25-50, the length-related characters (face) and mandible had relatively higher growth rates, but the width-related characters (braincase) were retarded in growth. The relative growth coefficient $(\alpha)$ against the condylobasal length was highest in the nasal length and height of mandible, and lowest in the interorbital breadth and breadth of occipital foramen. Relative ages of the field specimens were determined by age classes (I-VI) of tooth wear in laboratory specimens. Analyses of the skull variation in field specimens by univariate and multivariate techniques revealed that the greatest length had the lowest coefficients of variation with significant subsets which spanned age class II through VI, and had also the greatest loading on the first principal component. Comparison of skull growth in age class II (days 26-35) between laboratory and field conditions indicated that the field specimens had a stronger dorsal flexion of the anterior cranial base, and were longer in the lengths of mandible and lower molar series than were the laboratory specimens.
\end{abstract}

\section{INTRODUCTION}

Patterns of craniometric variation including age determination in Apodemus have been examined in Europe (Adamczewska-Andrzejewska, 1973, Haitlinger, 1962 and Sikorski, 1982 for A. agrarius; Delany, 1970, Delany and Davis, 1961 and Haitlinger, 1969 for A. sylvaticus, etc.), Japan (Imaizumi, 1962 and Miyao et al., 1968, for A. speciosus; Miyao and Mōri, 1968 and Yoshida, 1984 for A. argenteus, etc.) and Taiwan (Tanaka, 1942 for A. agrarius), which are based on measuring random samples of unknown-age skulls. Such studies serve for understanding the fundamental sources of intrapopulational (sexual dimorphism, age and individual) and interpopulational variation.

However, with respect to known-age specimens from the laboratory colony, there have been few studies on both the absolute skull growth and the tooth wear in A podemus, except for the report of Gurnell and Knee (1984) on the relationships between age and seventeen biometric variables in A. sylvaticus, and suggesting that tooth wear is still useful for assigning the age of young wild-caught mice in a population.

The purpose of this study was to examine 1) the absolute and relative growth rates

\footnotetext{
* Reprint request to the second author.
} 
of skull dimensions in known-age specimens of the Formosan wood mouse (A. semotus), 2) the pattern of eruption and wear in the upper molars of reared specimens, by which the standard age class was established and applied in determining relative ages of field specimens, and 3) the quantitative extent of age, sex and individual variation, and interrelationships among cranial characters in the field specimens. Another aim was to analyze skull growth and variation in this species and to discuss difference in skull growth between laboratory and field conditions.

\section{MATERIALS AND METHODS}

\section{Materials}

\section{1) Laboratory specimens}

The specimens were taken from a breeding colony in the Zoological Laboratory, Faculty of Agriculture, Kyushu University which established in 1984 from wild mice trapped in Alisan Alpine Forest Park (23 $31^{\prime} \mathrm{N}, 2,200 \mathrm{~m}$ elevation), lying $75 \mathrm{~km}$ east Chia-Yi County, Central Taiwan. Mice were reared in an air-conditioned room and illuminated by fluorescent lights on a $12 \mathrm{hr}$ light : $12 \mathrm{hr}$ dark cycle. Temperature was about $20^{\circ} \mathrm{C}$. Relative humidity was not regulated.

Four specimens ( 2 males; 2 females) of known-age mice from each age group of days $0,4,8,12,16,20,25,30,40$ and 50 , and exceptionally three specimens ( 2 males and 1 female) from the age group of day 35, were analyzed for both the absolute and the relative growth. Their absolute ages were used as criteria for young relative age classes (I-III) of field specimens on the basis of abrasive degree of the teeth in accordance with the method of Fujimaki (1966) for A. argenteus. The absolute growth rate of the skull was estimated according to the following postnatal growth periods (Lin et al., 1993): (1) the first period at the age of days O-12 (the neonate and transition periods on days O-14); (2) the second period on days 16-20 (the socialization period on days 15-24); (3) the third period on days $25-50$ (the juvenile period from day 25 to sexual maturity). Furthermore, one male specimen at the age of day 60 and of day 70, two specimens ( 1 male and 1 female) aged 100 days, one male specimen aged 180 days and three specimens ( 2 males and 1 female) aged 540 days were added for analysis of the relative growth and for grouping into older age classes (IV-VI).

\section{2) Field specimens}

A total of 209 unknown-age specimens (133 males; 76 females), snap-trapped in the Alisan Alpine Forest Park, from April 1985 to March 1986, was available for analysis. The mean temperature ranged from $5.5^{\circ} \mathrm{C}$ to $14.5^{\circ} \mathrm{C}$, being relatively higher during JuneJuly. Annual rainfall averaged about $4,000 \mathrm{~mm}$. The longest and shortest daylengths were $13 \mathrm{hrs}$ and $33 \mathrm{~min}$. in June and $10 \mathrm{hrs}$ and $44 \mathrm{~min}$. in December, respectively. Although recognition of the absolute age was usually impossible in the wild-taken specimens, the relative age was divided into five classes (II-VI) based on the above six age classes in the laboratory specimens, because no specimen belonging to age class I was caught in the field.

\section{Measurements}

The following fifteen variables of each skull were measured with dial calipers and 
recorded to the nearest $0.05 \mathrm{~mm}$ (Fig. 1); greatest length (GL), condylobasal length (CL), basilar length (BL), palatilar length (PL), length of incisive foramen (LIF), length of upper diastema (LUD), length of upper molar series (LUM), nasal length (NL), breadth of rostrum (BR), interorbital breadth (IB), zygomatic breadth (ZB), breadth of occipital foramen (BOF), length of mandible (LM), length of lower molar series (LLM), height of mandible (HM), in accordance with the method of Yoshida (1983) for A. speciosus. Mean values were given with standard deviation.

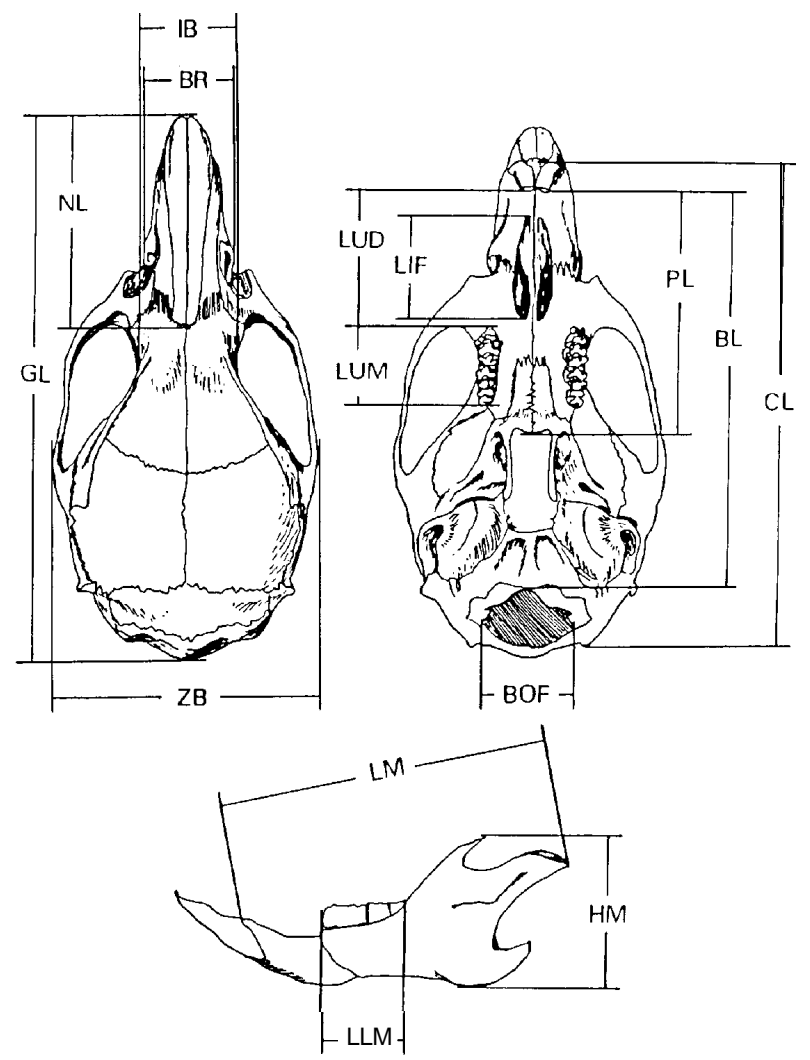

Fig. 1. Schematic representation of the skull measurements in Apodemus semotus. See text for explanation of abbreviations.

\section{Statistical analysis}

\section{1) Laboratory specimens}

Data on the absolute and relative skull growth were dealt with in both sexes combined, and were not used for analyzing craniometric variation of the specimens by the univariate and multivariate techniques, because sample size presented here was considered to be insufficient both for analysis of differences between sexes and for quantification of the variation. The relationship of the 14 dimensions each against the condylobasal length was examined by the allometry formula $\left(\mathrm{Y}=\mathrm{bx}^{\alpha}\right)$ (Simpson et al., 
1960); the relative growth coefficients (a), initial growth indices (log b) and correlation coefficients ( $\mathrm{r}$, converted from $\mathrm{R}^{2}$ values) also were calculated.

\section{2) Field specimens}

Concerning the field specimens which were placed into the above relative five age classes (II-VI) and sexed, separate $5 \times 2$ (age and sex) analyses of variance were performed on each skull dimension using the ANOVA (analysis of variance) portion of

Table 1. Measurements (Mean $\pm \mathrm{SD}$ ) of the skull according to ages in laboratory-reared Apodemus semotus.

\begin{tabular}{|c|c|c|c|c|c|}
\hline \multirow{2}{*}{$\begin{array}{l}\text { Age } \\
\text { (days) }\end{array}$} & \multirow{2}{*}{ Period } & \multicolumn{4}{|c|}{ Dimension* } \\
\hline & & GL & $\mathrm{CL}$ & $\mathrm{BL}$ & PL \\
\hline 0 & $1 \mathrm{st}$ & $10.30 \pm 0.52$ & - & $7.91 \pm 0.70$ & - \\
\hline 4 & & $14.19 \pm 1.15$ & $13.31 \pm 0.40$ & $11.91 \pm 0.50$ & - \\
\hline 8 & & $17.65 \pm 0.31$ & $16.10 \pm 0.39$ & $13.70 \pm 0.39$ & - \\
\hline 12 & & $20.56 \pm 0.36$ & $18.41 \pm 0.59$ & $15.51 \pm 0.62$ & - \\
\hline 16 & $2 \mathrm{nd}$ & $21.15 \pm 1.08$ & $18.88 \pm 0.90$ & $15.28 \pm 0.82$ & $7.79 \pm 0.27$ \\
\hline 20 & & $23.49 \pm 0.20$ & $20.70 \pm 0.20$ & $15.26 \pm 2.94$ & $9.23 \pm 0.56$ \\
\hline 25 & $3 \mathrm{rd}$ & $24.24 \pm 0.11$ & $21.35 \pm 0.16$ & $17.51 \pm 0.21$ & $9.80 \pm 0.32$ \\
\hline 30 & & $24.94 \pm 0.32$ & $22.17 \pm 0.50$ & $18.78 \pm 0.73$ & $10.01 \pm 0.22$ \\
\hline 35 & & $25.67 \pm 0.61$ & $22.85 \pm 0.43$ & $18.93 \pm 0.42$ & $10.33 \pm 0.18$ \\
\hline 40 & & $25.36 \pm 0.65$ & $22.89 \pm 0.77$ & $18.86 \pm 0.31$ & $10.31 \pm 0.18$ \\
\hline 50 & & $26.59 \pm 0.73$ & $23.51 \pm 0.62$ & $19.45 \pm 0.41$ & $10.55 \pm 0.47$ \\
\hline 60 & & 25.45 & 22.55 & 18.80 & 10.15 \\
\hline 70 & & 26.70 & 23.80 & 19.30 & 10.90 \\
\hline 100 & & $27.05 \pm 0.07$ & $23.78 \pm 0.04$ & $19.63 \pm 0.18$ & $10.55 \pm 0.07$ \\
\hline 180 & & 27.55 & 24.65 & 20.45 & 10.60 \\
\hline \multirow[t]{2}{*}{540} & & $27.77 \pm 0.38$ & $24.90 \pm 0.38$ & $20.50 \pm 0.23$ & $10.98 \pm 0.19$ \\
\hline & & LIF & LUD & LUM & NL \\
\hline 0 & $1 \mathrm{st}$ & $1.75 \pm 0.20$ & - & & $2.83 \pm 0.13$ \\
\hline 4 & & $2.10 \pm 0.52$ & - & - & $4.49 \pm 0.24$ \\
\hline 8 & & $3.41 \pm 0.26$ & - & & $5.85 \pm 0.41$ \\
\hline 12 & & $3.45 \pm 0.39$ & - & - & $7.59 \pm 0.24$ \\
\hline 16 & 2nd & $3.88 \pm 0.21$ & $4.89 \pm 0.34$ & $3.23 \pm 0.25$ & $7.86 \pm 0.69$ \\
\hline 20 & & $3.50 \pm 0.18$ & $5.20 \pm 0.23$ & $3.93 \pm 0.38$ & $8.89 \pm 0.21$ \\
\hline 25 & $3 \mathrm{rd}$ & $3.71 \pm 0.09$ & $5.63 \pm 0.03$ & $4.14 \pm 0.13$ & $9.54 \pm 0.44$ \\
\hline 30 & & $3.60 \pm 0.50$ & $5.63 \pm 0.35$ & $4.00 \pm 0.08$ & $9.90 \pm 0.60$ \\
\hline 35 & & $4.02 \pm 0.63$ & $5.73 \pm 0.32$ & $4.13 \pm 0.10$ & $9.63 \pm 0.71$ \\
\hline 40 & & $4.44 \pm 0.21$ & $6.05 \pm 0.12$ & $4.10 \pm 0.04$ & $10.46 \pm 0.78$ \\
\hline 50 & & $4.22 \pm 0.76$ & $6.45 \pm 0.47$ & $4.14 \pm 0.05$ & $10.28 \pm 0.41$ \\
\hline 60 & & 4.15 & 5.50 & 4.35 & 9.75 \\
\hline 70 & & 4.10 & 5.80 & 4.15 & 10.05 \\
\hline 100 & & $4.25 \pm 0.21$ & $5.88 \pm 0.32$ & $4.05 \pm 0.14$ & $9.90 \pm 0.64$ \\
\hline 180 & & 4.25 & 6.20 & 4.10 & 11.90 \\
\hline 540 & & $4.15 \pm 0.09$ & $6.77 \pm 0.03$ & $4.12 \pm 0.13$ & $11.38 \pm 0.55$ \\
\hline
\end{tabular}

*See text for explanation of abbreviations. 
the univariate analyses in the SAS (statistical analysis system) program package. The five means for each dimension were compared for significant differences at the 0.05 level with the Duncan's Multiple Range Test. Furthermore, the mean, standard deviation and coefficients of variation $(\mathrm{CV})$ also were determined. It is important to note that the cranial measurements with CV's of below 6.00 indicate a relatively low degree of variability within the population (Matson and Shump, 1980). Multivariate analyses were done using the principal component analysis (Manly, 1986).

Table 1. -continued

\begin{tabular}{|c|c|c|c|c|c|}
\hline & & $\mathrm{BR}$ & IB & ZB & $\mathrm{BOF}$ \\
\hline 0 & $1 \mathrm{st}$ & $2.59 \pm 0.48$ & $2.49 \pm 0.35$ & $5.36 \pm 0.58$ & $1.93 \pm 0.39$ \\
\hline 4 & & $3.48 \pm 0.13$ & $4.05 \pm 0.39$ & $7.38 \pm 0.59$ & $3.25 \pm 0.41$ \\
\hline 8 & & $3.45 \pm 0.08$ & $4.41 \pm 0.19$ & $8.74 \pm 0.57$ & $3.53 \pm 0.08$ \\
\hline 12 & & $3.75 \pm 0.18$ & $5.34 \pm 0.22$ & $10.44 \pm 0.22$ & $4.28 \pm 0.17$ \\
\hline 16 & 2nd & $3.70 \pm 0.20$ & $5.26 \pm 0.43$ & $10.49 \pm 0.56$ & $4.30 \pm 0.13$ \\
\hline 20 & & $3.86 \pm 0.10$ & $5.54 \pm 0.16$ & $11.51 \pm 0.21$ & $4.66 \pm 0.13$ \\
\hline 25 & $3 \mathrm{rd}$ & $3.93 \pm 0.20$ & $5.50 \pm 0.07$ & $11.65 \pm 0.32$ & $4.88 \pm 0.12$ \\
\hline 30 & & $3.85 \pm 0.19$ & $5.84 \pm 0.25$ & $12.10 \pm 0.07$ & $4.73 \pm 0.19$ \\
\hline 35 & & $4.03 \pm 0.49$ & $5.70 \pm 1.15$ & $12.22 \pm 0.10$ & $4.90 \pm 0.13$ \\
\hline 40 & & $4.05 \pm 0.23$ & $5.75 \pm 0.13$ & $12.24 \pm 0.34$ & $4.68 \pm 0.16$ \\
\hline 50 & & $4.01 \pm 0.27$ & $5.73 \pm 0.67$ & $12.63 \pm 0.19$ & $4.74 \pm 0.13$ \\
\hline 60 & & 4.35 & 5.80 & 12.25 & 4.65 \\
\hline 70 & & 4.35 & 5.85 & 12.65 & 4.75 \\
\hline 100 & & $4.15 \pm 0.14$ & $5.83 \pm 0.11$ & $12.73 \pm 0.04$ & $4.80 \pm 0.21$ \\
\hline 180 & & 4.65 & 5.50 & 12.90 & 5.00 \\
\hline \multirow[t]{2}{*}{540} & & $4.42 \pm 0.21$ & $6.35 \pm 0.46$ & $12.85 \pm 0.46$ & $4.83 \pm 0.15$ \\
\hline & & LM & LIM & $\mathrm{HM}$ & \\
\hline 0 & $1 \mathrm{st}$ & $6.65 \pm 0.25$ & - & $1.99 \pm 0.20$ & \\
\hline 4 & & $8.33 \pm 0.35$ & - & $3.10 \pm 0.50$ & \\
\hline 8 & & $9.75 \pm 0.25$ & & $3.70 \pm 0.38$ & \\
\hline 12 & & $10.95 \pm 0.32$ & - & $4.56 \pm 0.13$ & \\
\hline 16 & 2nd & $11.08 \pm 0.45$ & $2.49 \pm 0.23$ & $4.40 \pm 0.09$ & \\
\hline 20 & & $12.39 \pm 0.10$ & $2.70 \pm 0.15$ & $5.33 \pm 0.28$ & \\
\hline 25 & $3 \mathrm{rd}$ & $12.45 \pm 0.15$ & $3.03 \pm 0.38$ & $5.71 \pm 0.18$ & \\
\hline 30 & & $13.00 \pm 0.54$ & $2.96 \pm 0.27$ & $6.18 \pm 0.21$ & \\
\hline 35 & & $14.60 \pm 2.53$ & $3.33 \pm 0.20$ & $6.25 \pm 0.13$ & \\
\hline 40 & & $13.06^{\prime} \pm 0.15$ & $3.41 \pm 0.29$ & $6.24 \pm 0.39$ & \\
\hline 50 & & $13.45 \pm 0.51$ & $3.31 \pm 0.21$ & $6.43 \pm 0.41$ & \\
\hline 60 & & 13.10 & 3.25 & 6.10 & \\
\hline 70 & & 13.90 & 3.15 & 6.85 & \\
\hline 100 & & $13.43 \pm 0.18$ & $3.30 \pm 0.07$ & $6.40 \pm 0.21$ & \\
\hline 180 & & 13.55 & 3.20 & 6.25 & \\
\hline 540 & & $13.90 \pm 0.30$ & $3.20 \pm 0.23$ & $7.00 \pm 0.07$ & \\
\hline
\end{tabular}




\section{RESULTS}

\section{Skull growth in the laboratory specimens}

1) Absolute growth

The data on the 15 measurements and their percentage increases of the skulls are presented in Tables 1 and 2, respectively. Their absolute sizes grew very rapidly during the first and second periods from day 0 to day 24 (Fig. 2). At the first period, the greatest length was $10.30 \pm 0.52 \mathrm{~mm}$ at birth, reaching $20.56 \pm 0.36 \mathrm{~mm}$ on day 12 $(0.86 \mathrm{~mm} /$ day with an increase of $99.6 \%)$. The rapid growth pattern was also found in the zygomatic breadth $(0.42 \mathrm{~mm} /$ day; $94.6 \%)$, length of incisive foramen $(0.14 \mathrm{~mm} /$ day; $97.1 \%)$, interorbital breadth $(0.24 \mathrm{~mm} /$ day; $116.6 \%)$, breadth of occipital foramen $(0.20$ $\mathrm{mm} /$ day; $122.1 \%)$, height of mandible $(0.22 \mathrm{~mm} /$ day; $129.6 \%)$ and nasal length $(0.40$ $\mathrm{mm} /$ day; $168 \%$ ); however, at this period, the breadth of rostrum and length of mandible showed only moderate increases with $44.9 \%(0.10 \mathrm{~mm} /$ day $)$ and $64.7 \%(0.36 \mathrm{~mm} /$ day $)$, respectively.

As to the second period, the high incremental percentage of the skull measurements continued also during the period from day 16 to day 20 , except for the length of incisive foramen and interorbital breadth with slow increases of $7.3 \%$ and $2.1 \%$, respectively, During the third period on days $25-50$, the growth rate of the 10 characters was less than $10 \%$, but the condylobasal length, basilar length, length of incisive

Table 2. Percentage increases* of skull mean measurements during three growth periods in laboratory-reared Apodemus semotus.

\begin{tabular}{|c|c|c|c|}
\hline \multirow{2}{*}{ Dimension ${ }^{\dagger}$} & \multicolumn{3}{|c|}{ Period ${ }^{\ddagger}$} \\
\hline & $1 \mathrm{st}$ & $2 \mathrm{nd}$ & $3 \mathrm{rd}$ \\
\hline GL & 99.6 & 17.9 & 9.7 \\
\hline $\mathrm{CL}$ & 38.38 & 16.0 & 10.1 \\
\hline BL & 96.0 & 12.9 & 11.1 \\
\hline PL & & 25.9 & 7.7 \\
\hline LIF & 97.1 & 7.6 & 13.5 \\
\hline LUD & - & 15.1 & 14.7 \\
\hline LUM & - & 24.0 & 3.5 \\
\hline NL & 168.0 & 25.7 & 7.2 \\
\hline BR & 44.9 & 4.7 & 2.2 \\
\hline IB & 116.6 & 2.1 & 4.1 \\
\hline $\mathrm{ZB}$ & 94.6 & 11.6 & 8.4 \\
\hline $\mathrm{BOF}$ & 122.1 & 12.9 & 0.0 \\
\hline LM & 64.7 & 13.7 & 8.0 \\
\hline LLM & - & 21.6 & 9.5 \\
\hline HM & 129.6 & 25.2 & 12.5 \\
\hline
\end{tabular}

* Percentage increase $=(B-A) \times 100 / A$; A: the length on the first day in each period, B: the length on the last day in each period.

+ See text for explanation of abbreviations.

¥ 1st period, day O-12; 2nd period, days 16-24; 3rd period, days $25-50$.

$\S$ Estimated at the age of days 4-12. 


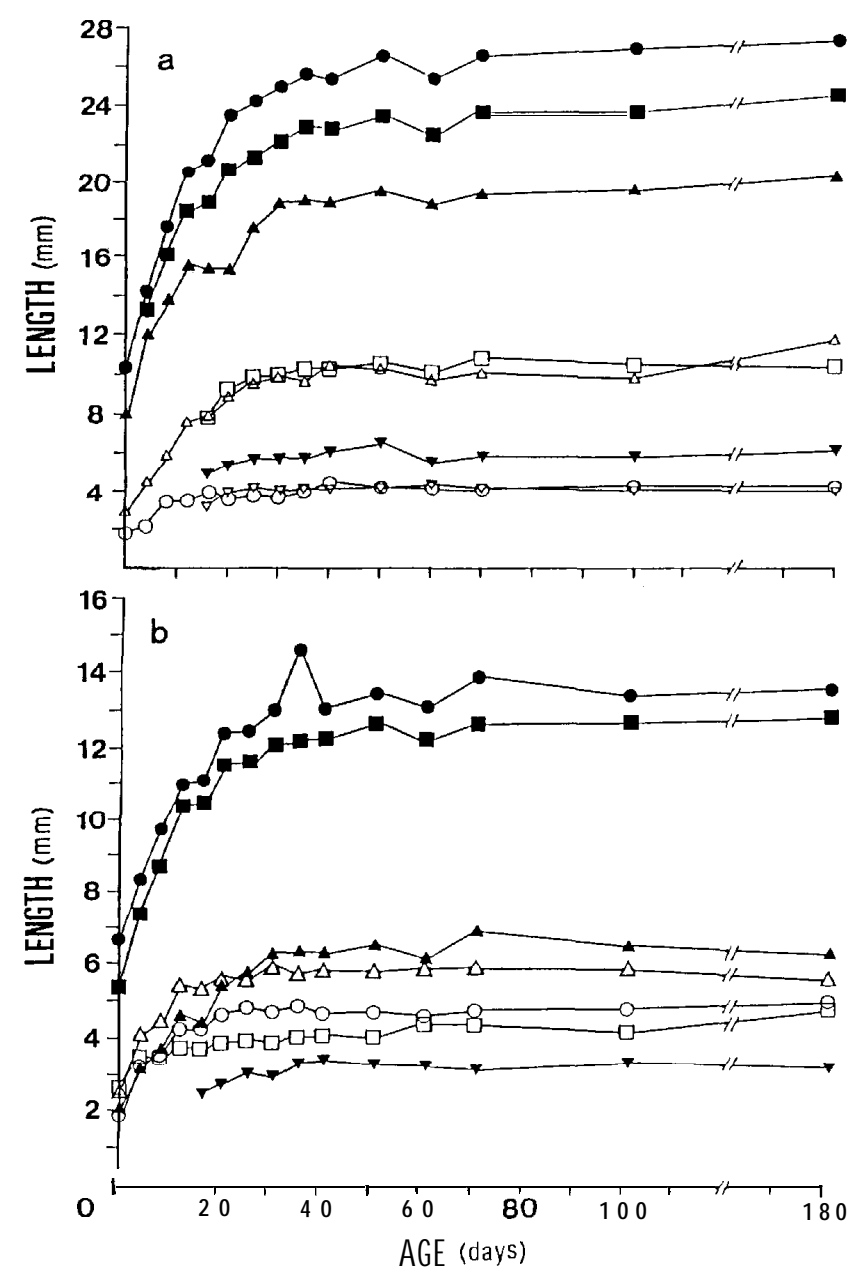

Fig. 2. Growth in the skull measurements in Apodemus semotus. (a) Length-related

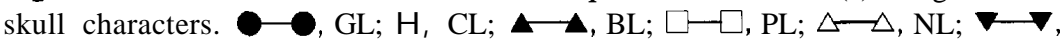
LUD; $\nabla \longrightarrow$, LUM; $\bigcirc-$, LIF. (b) Width-related skull characters and mandibular characters. - LM; H, ZB; $\longrightarrow$, HM; $\square \triangle$, IB; $\bigcirc-\mathrm{O}$, BOF; $\square \square$, BR; $\longrightarrow$, LIM. See text for explanation of abbreviations.

foramen, length of upper diastema and height of mandible continued to grow with slight increases from $10.1 \%$ to $14.7 \%$ (Table 2). Afterward, on days 60 and 70 , the skull measurements attained almost the same size as in adults on days 100 and 180, and their increases nearly ceased on day 60 , so that the growth curves became parallel to the abscissa (Fig. 2).

\section{2) Relative growth}

The relative growth coefficients (a), initial growth indices (log b) and correlation 
coefficients ( $r$ ) of each dimension of the 14 characters against the condylobasal length are given in Table 3 .

The correlation coefficients were high for 6 dimensions of the skull, i.e. the greatest length $(0.995)$, basilar length $(0.990)$, length of mandible $(0.987)$, zygomatic breadth $(0.982)$, nasal length $(0.981)$ and height of mandible $(0.978)$. On the other hand, the correlation coefficients for the length of upper and lower molar series were low ( 0.724 and 0.657 , respectively). Regarding the dimensions along the long axis of the skull, the relative growth coefficients (a) became lower in the following order: nasal length $(1.450)$, palatilar length $(1,138)$ and basilar length $(0.892)$. As to the dimensions parallel to the short axis of the skull, the $\alpha$ was lowest in the interorbital breadth (0.643), and highest in the zygomatic breadth (0.894). In addition, the $\alpha$ values of the mandibular length and height were 0.852 and 1.387 , respectively; the latter value was one of the highest for the 14 dimensions of the skull.

Table 3 . Relative growth coefficients $(\alpha)$, initial growth indices (log b) and correlation coefficients (r) of 14 dimensions against the condylobasal length in laboratory-reared Apodemus semotus.

\begin{tabular}{|c|c|c|c|}
\hline Dimension* & $\alpha$ & $\log b$ & $\mathrm{r}$ \\
\hline GL & 0.900 & -0.046 & 0.995 \\
\hline $\mathrm{BL}$ & 0.892 & 0.061 & 0.990 \\
\hline PL & 1.138 & -0.539 & 0.905 \\
\hline LIF & 1.006 & -0.749 & 0.830 \\
\hline LUD & 1.042 & -0.646 & 0.795 \\
\hline LUM & 0.759 & -0.424 & 0.724 \\
\hline NL & 1.450 & -0.966 & 0.981 \\
\hline BR & 0.887 & 0.082 & 0.807 \\
\hline IB & 0.643 & -0.111 & 0.897 \\
\hline ZB & 0.894 & -0.127 & 0.982 \\
\hline $\mathrm{BOF}$ & 0.648 & -0.205 & 0.907 \\
\hline LM & 0.852 & -0.040 & 0.987 \\
\hline LLM & 1.075 & -0.959 & 0.657 \\
\hline HM & 1.387 & -1.094 & 0.978 \\
\hline
\end{tabular}

*See text for explanation of abbreviations.

\section{Tooth wear and chronological age}

\section{1) Laboratory specimens}

A series of six tooth classes was established on the pattern of eruption and wear mainly in the upper molars of the laboratory specimens. These tooth classes were used as criteria for relative age classes of the field specimens as follows:

Class I - Sucklings at the age of days O-25 before weaning. On days 12-16, both $\mathrm{M}^{1}$ and $\mathrm{M}_{1}$ began to erupt. On day 16 , the anterior part of $\mathrm{M}^{2}$ appeared. On day $25, \mathrm{M}^{3}$ erupted in some individuals, but did not reach the crown level of $\mathbf{M}^{1}$ and $\mathbf{M}^{2}$. Cusps of $\mathrm{M}^{1}$ and $\mathrm{M}^{2}$ had no trace of abrasion (Fig. 3).

Class II - Juveniles at the age of days 26-35. $\mathrm{M}^{1}$ and $\mathrm{M}^{2}$ were well developed and had faint traces of abrasion on cusps. $\mathrm{M}^{3}$ erupted, but was not fully developed; the cusps 1 and 3 were disconnected from an irregular loph consisting of the cusps 2, 4 and 

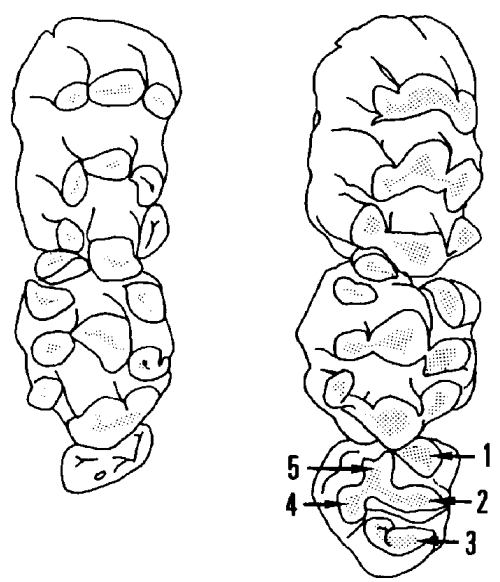

II

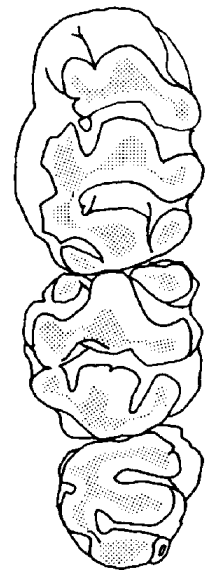

IV

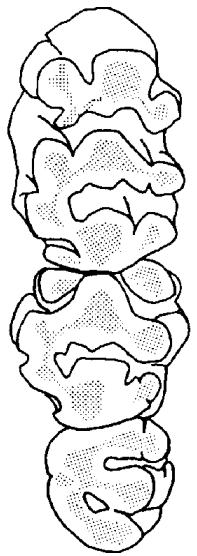

V

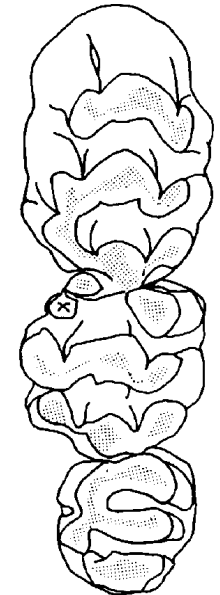

III

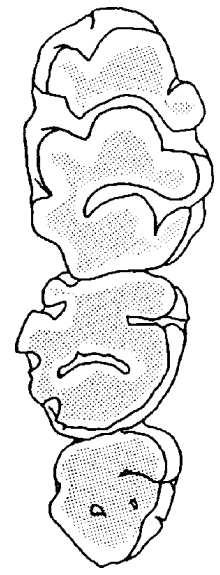

V

Fig. 3. Model tooth for determining age classes using laboratory specimens. I-VI, age classes; 1-5, cusps.

5 separated from one another. Almost no abrasion on the cusps 1-5 was found (Fig. 3).

Class III - Subadults at the age of days 36-50. $\mathrm{M}^{1}$ and $\mathrm{M}^{2}$ were slightly worn, $\mathrm{M}^{3}$ was beginning to wear, but the 5 cusps were still clearly distinguishable. The cusp 1 began to connect with the cusp 5 (Fig. 3).

Class IV - Adolescents at the age of day 51 to below day $100 . \mathrm{M}^{3}$ was fairly worn, and the enamel ridges of the cusps 1 and 5 were joined together (Fig. 3).

Class V - Adults at the age of days 100-180. $\mathrm{M}^{1}$ and $\mathrm{M}^{2}$ became devoid of cusps and suffered very heavy abrasion. $\mathrm{M}^{3}$ was further worn, the enamel ridges between the cusps 2 and 3 and between the cusps 3 and 4 disappeared, and the cusps 4 and 5 fused 
to form a semicircle (Fig. 3).

Class VI - Seniles at the age of above 180 days. $\mathrm{M}^{3}$ was heavily worn and the enamel ridge between the cusps 1 and 2 disappeared, and the border of enamel surrounded only the lateral surface of the tooth (Fig. 3).

\section{2) Field specimens}

The number of specimens belonging to each relative age class determined by the above tooth-criteria is shown in Table 4: age class II, 12 males and 7 females; age class III, 25 males and 24 females; age class IV, 32 males and 21 females; age class V, 34 males and 14 females; age class VI, 28 males and 12 females. As to the seasonal changes in age structure of the field population, spring-and autumn-born generations, belonging to young age classes (II and III), entering into the population were clearly distinguishable. The former began to appear in late spring (May) and the latter did from November to January. On the contrary, few young specimens appeared in MarchApril, June and October. Many overwintering individuals belonging to the older age classes (IV-VI), appeared from February to May.

Table 4. Number of field specimens according to age classes in Apodemus semotus.

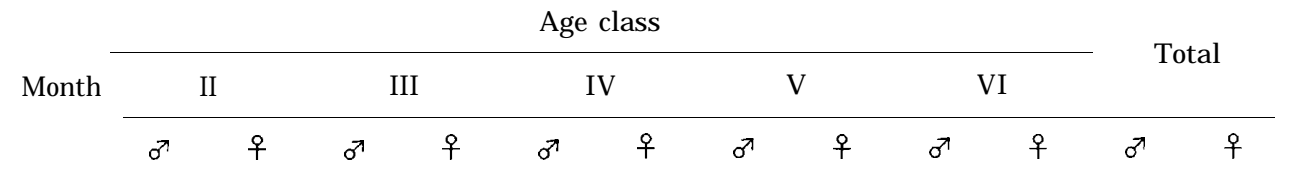

\begin{tabular}{|c|c|c|c|c|c|c|c|c|c|c|c|c|}
\hline \multicolumn{13}{|l|}{1985} \\
\hline Apr. & 0 & 0 & 0 & 0 & 3 & 3 & 3 & 2 & 2 & 1 & 8 & 6 \\
\hline May. & 3 & 0 & 3 & 0 & 4 & 2 & 6 & 1 & 4 & 2 & 20 & 5 \\
\hline Jun. & 0 & 0 & 2 & 0 & 3 & 1 & 1 & 0 & 1 & 2 & 7 & 3 \\
\hline Jul. & 0 & 2 & 0 & 3 & 0 & 2 & 3 & 0 & 3 & 1 & 6 & 8 \\
\hline Aug. & 0 & 0 & 2 & 2 & 2 & 1 & 4 & 2 & 0 & 0 & 8 & 5 \\
\hline Sep. & 0 & 0 & 3 & 2 & 0 & 0 & 3 & 1 & 2 & 1 & 8 & $\begin{array}{l}4 \\
7\end{array}$ \\
\hline Detv. & $\theta$ & 1 & 0 & 2 & 0 & 0 & 8 & 0 & 8 & 0 & 16 & 3 \\
\hline Dec. & 1 & 1 & 3 & 5 & 2 & 2 & 1 & 1 & 2 & 0 & 9 & 9 \\
\hline \multicolumn{13}{|l|}{1986} \\
\hline Jan. & 2 & 2 & 4 & 6 & 6 & 4 & 1 & 2 & 2 & 2 & 15 & 16 \\
\hline Feb. & 0 & 0 & 6 & 2 & 8 & 3 & 4 & 2 & 5 & 0 & 23 & 7 \\
\hline Mar. & 1 & 0 & 1 & 1 & 3 & 2 & 3 & 1 & 2 & 1 & 10 & 5 \\
\hline Total & 12 & 7 & 25 & 24 & 32 & 21 & 34 & 14 & 28 & 12 & 131 & 78 \\
\hline
\end{tabular}

\section{Skull variation in the field specimens}

Many field specimens were used for examining nongeographic variation in the cranial characters, three types of which were examined - age, secondary sexual and individual. 
Table 5. Basic statistics and results of univariate analyses (Duncan's Multiple Range Test and ANOVA) of 15 cranial measurements in wild-taken Apodemus semotus.

\begin{tabular}{|c|c|c|c|c|c|c|}
\hline $\begin{array}{l}\text { Age } \\
\text { class }\end{array}$ & $\mathrm{N}$ & Mean & SD & $\mathrm{c} \mathrm{v}$ & $\begin{array}{c}\text { Duncan's } \\
\text { test }\end{array}$ & $F$ \\
\hline \multicolumn{7}{|c|}{ Greatest length } \\
\hline II & 16 & 25.41 & 1.01 & 3.98 & \multirow{5}{*}{1} & $F_{\mathrm{age}}=33.71^{*}$ \\
\hline III & 48 & 26.00 & 0.94 & 3.62 & & \\
\hline IV & 53 & 26.66 & 0.79 & 2.96 & & $F_{\mathrm{sex}}=1.98 " '$ \\
\hline $\mathrm{V}$ & 47 & 27.14 & 0.91 & 3.36 & & \\
\hline VI & 39 & 27.70 & 0.68 & 2.46 & & $F_{\text {lnt }}=0.85^{\prime \prime \prime}$ \\
\hline \multicolumn{7}{|c|}{ Condylobasal length } \\
\hline II & 16 & 22.77 & 0.92 & 4.06 & \multirow{5}{*}{${ }_{1}$} & $F_{\text {age }}=38.36^{*}$ \\
\hline III & 49 & 23.21 & 0.90 & 3.89 & & \\
\hline IV & 53 & 23.86 & 0.83 & 3.46 & & $F_{\text {sex }}=1.09 " '$ \\
\hline $\mathrm{V}$ & 48 & 24.49 & 0.66 & 2.71 & & \\
\hline VI & 40 & 28.84 & 0.61 & 2.47 & & $F_{\text {tnt }}=0.27^{\prime \prime \prime}$ \\
\hline \multicolumn{7}{|c|}{ Basilar length } \\
\hline II & 13 & 18.95 & 1.01 & 5.35 & \multirow[t]{6}{*}{1} & $F_{\mathrm{age}}=4.52^{*}$ \\
\hline III & 47 & 19.30 & 0.99 & 5.13 & & \\
\hline IV & 49 & 20.01 & 0.82 & 4.11 & & $F_{\mathrm{sex}}=3.02 " ' \prime$ \\
\hline VI & 40 & 20.33 & 3.35 & 16.47 & & \\
\hline $\mathrm{V}$ & 43 & 20.48 & 0.63 & 3.05 & & $F_{\mathrm{int}}=2.27^{\mathrm{ns}}$ \\
\hline \multicolumn{6}{|c|}{ Palatilar length } & \\
\hline & 17 & & & & \multirow[t]{3}{*}{1} & $F_{\text {age }}=17.33^{*}$ \\
\hline III & 49 & 10.98 & 0.52 & 4.80 & & \\
\hline $\begin{array}{r}\text { IV } \\
\text { V }\end{array}$ & $\begin{array}{l}53 \\
48\end{array}$ & 11.36 & 0.46 & 3.92 & & $F_{\mathrm{sex}}=3.53$ \\
\hline VI & 40 & 11.65 & 0.42 & 3.60 & 1 & $F_{\text {Int }}=0.00^{\prime \prime \prime}$ \\
\hline
\end{tabular}

Length of incisive foramen

$\begin{array}{rll}\text { III } & 49 & 4.83 \\ \text { II } & 18 & 4.98 \\ \text { IV } & 53 & 5.15 \\ \text { VI } & 40 & 5.2 \\ \text { V } & 48 & 5.39\end{array}$

\begin{tabular}{ll|l}
0.51 & 10.66 \\
0.63 & 12.66 \\
0.90 & 17.49 \\
0.58 & 10.98 \\
0.56 & 10.37 &
\end{tabular} \mid $\begin{aligned} & F_{\text {age }}=5.14^{*} \\
& F_{\text {sex }}=0.08^{\prime}, \\
& \end{aligned}$

Length of upper diastema

\begin{tabular}{|c|c|c|c|c|c|}
\hline II & 18 & 6.77 & 0.47 & 6.94 & $F_{\text {age }}=2.83^{*}$ \\
\hline III & 49 & 6.88 & 0.48 & 6.93 & \\
\hline IV & 53 & 6.97 & 1.06 & 15.18 & $F_{\text {sex }}=0.05^{\prime}$ \\
\hline VI & 39 & & & & \\
\hline V & 48 & 7.29 & 0.38 & 16.68 & $F_{\text {lnt }}=1.15^{\prime}$ \\
\hline
\end{tabular}

Length of upper molar series

$\begin{array}{rrr}\text { III } & 49 & 4.19 \\ & 48 & 4.25 \\ \text { I:: } & 53 & 4.25 \\ \text { II } & 18 & 4.29 \\ \text { VI } & 39 & 4.35\end{array}$

$\begin{array}{rr}0.34 & 8.20 \\ 0.24 & 5.72 \\ 0.31 & 7.28 \\ 0.49 & 11.33 \\ 0.51 & 11.6\end{array}$

$F_{\text {age }}=1.09^{\text {ns }}$

$F_{\text {sex }}=1.09 " '$

$F_{\text {int }}=1.11^{\prime \prime \prime}$

Nasal length

\begin{tabular}{rrrrr|l} 
II & 18 & 9.30 & 1.10 & 11.81 & $F_{\text {age }}=1.76^{\text {ns }}$ \\
III & 49 & 9.52 & 1.44 & 15.14 & $F_{\text {sex }}=0.01^{\text {ns }}$ \\
V & 47 & 10.15 & 1.49 & 14.70 & \\
IV & 53 & 10.24 & 2.99 & 29.24 & $F_{\text {lnt }}=0.24$ "” \\
VI & 40 & 10.33 & 1.73 & 16.76 &
\end{tabular}


Table 5. - continued.

\begin{tabular}{|c|c|c|c|c|c|c|}
\hline $\begin{array}{l}\text { Age } \\
\text { class }\end{array}$ & $\mathrm{N}$ & Mean & $\mathrm{SD}$ & $\mathrm{c} \mathrm{v}$ & $\begin{array}{l}\text { Duncan's } \\
\text { test }\end{array}$ & $F$ \\
\hline \multicolumn{7}{|c|}{ Breadth of rostrum } \\
\hline II & 18 & 4.33 & 0.21 & 4.95 & & $F_{\text {a ge }}=3.96^{*}$ \\
\hline III & 49 & 4.42 & 0.68 & 15.44 & & \\
\hline $\mathrm{V}$ & 47 & 4.61 & 1.00 & 21.68 & & $F_{\text {sex }}=1.88^{\prime \prime \prime}$ \\
\hline IV & 53 & 4.63 & 0.19 & 4.13 & & \\
\hline VI & 40 & 4.86 & 0.27 & 5.52 & 1 & $F_{\text {int }}=0.96 " '$ \\
\hline \multicolumn{7}{|c|}{ Interorbital breadth } \\
\hline II & 18 & 4.52 & 1.20 & 26.48 & & $F_{\text {age }}=1.99^{*}$ \\
\hline IV & 53 & 4.70 & 0.30 & 6.32 & & \\
\hline III & 49 & 4.73 & 0.32 & 6.86 & & $F_{\text {sex }}=0.02 " '$ \\
\hline V & 48 & 4.81 & & & & \\
\hline VI & 40 & 4.87 & 0.81 & 0.39 & & $F_{\mathrm{int}}=1.29^{\prime \prime \prime}$ \\
\hline \multicolumn{7}{|c|}{ Zygomatic breadth } \\
\hline II & 14 & 11.99 & & & & $F_{\text {age }}=6.87^{*}$ \\
\hline III & 46 & 12.18 & 0.99 & 8.76 & & \\
\hline IV & 53 & 12.48 & 0.55 & 4.40 & 1 & $F_{\text {sex }}=0.27^{\prime \prime \prime}$ \\
\hline $\mathrm{V}$ & 43 & 12.54 & 0.57 & 4.57 & & \\
\hline VI & 40 & 12.73 & 0.52 & 4.11 & & $F_{\text {Int }}=1.12 " '$ \\
\hline
\end{tabular}

Breadth of occipital foramen

\begin{tabular}{|c|c|c|c|c|c|}
\hline II & 17 & 4.47 & 1.18 & 26.49 & $F_{\text {age }}=1.06$ "' \\
\hline VI & 39 & 4.62 & 0.78 & 16.88 & \\
\hline III & 48 & 4.72 & 0.74 & 15.66 & $F_{\text {sex }}=3.42^{\prime \prime \prime}$ \\
\hline $\mathrm{V}$ & 46 & 4.74 & 0.20 & 4.27 & \\
\hline IV & 53 & 4.77 & 0.19 & 4.02 & $F_{\mathrm{Int}}=2.17^{\mathrm{ns}}$ \\
\hline
\end{tabular}

Length of mandible

\begin{tabular}{|c|c|c|c|c|c|c|}
\hline II & 17 & & & & & $F_{\text {age }}=13.96^{\prime}$ \\
\hline III & 49 & 13.56 & 0.85 & 5.98 & & \\
\hline IV & 52 & 14.21 & 0.65 & 4.60 & & $F_{\mathrm{sex}}=1.58^{\prime \prime \prime}$ \\
\hline $\mathrm{V}$ & 47 & 14.47 & 0.65 & 4.49 & & \\
\hline VI & 40 & 14.66 & 0.75 & 5.11 & 1 & $F_{\text {Int }}=0.34^{\prime \prime \prime}$ \\
\hline
\end{tabular}

Length of lower molar series

\begin{tabular}{rrrrr|c} 
II & 18 & 4.28 & 0.17 & 4.07 & $F_{\text {age }}=1.56 ” "$ \\
VI & 40 & 4.30 & 0.19 & 4.39 & \\
V & 48 & 4.38 & 0.25 & 5.65 & $F_{\text {sex }}=0.23 "$, \\
IV & 52 & 4.39 & 0.28 & 6.46 & \\
III & 49 & 4.39 & 0.22 & 5.11 & $F_{\text {lnt }}=0.69, "$,
\end{tabular}

Height of mandible

\begin{tabular}{rrrrr|c} 
III & 47 & 6.01 & 1.02 & 16.96 & $F_{\text {age }}=1.36 " ”$ \\
II & 17 & 6.09 & 0.54 & 8.80 & $F_{\text {sex }}=1.85^{\text {ns }}$ \\
IV & 47 & 6.31 & 0.51 & 8.11 & $F_{\text {lnt }}=0.52$ "” \\
V & 41 & 6.37 & 1.17 & 18.30 & \\
VI & 37 & 6.43 & 1.21 & 18.80 &
\end{tabular}

An asterisk denotes a significant $F$ value $(P<0.05)$. $\mathrm{ns}$, not significant at the 0.05 level by the F-test. 


\section{1) Age variation and secondary sexual variation}

Table 5 summarizes basic statistics and results of the univariate analyses for the 15 cranial measurements according to age classes. Age variation was significant in 10 measurements excluding 5 measurements mentioned below, but the length of upper and lower molar series, nasal length, breadth of occipital foramen and height of mandible did not vary with age. Results of the Duncan's Multiple Range Test analysis among age classes also are given in Table 5. Most skull measurements with significant difference of age variation showed overlap between adjacent age classes. However, three lengthrelated characters, i.e. the greatest length, condylobasal length and basilar length exhibited significant subsets which spanned age classes II through VI, II through IV and age class II, respectively.

Males and females did not differ significantly in any of the measurements, indicating no evidence of sexual dimorphism. Age $\mathbf{X}$ sex interaction also was not significant in the 15 measurements.

\section{2) Individual variation}

Individual variation was expressed most clearly in the coefficients of variation $(\mathrm{CV})$. The variability of the 15 cranial measurements was examined separately according to the five age classes (Table 5). In age class II, the interorbital breadth and breadth of occipital foramen were most variable $(\mathrm{CV}=26.48$ and 26.49 , respectively); the greatest length was least variable $(\mathrm{CV}=3.98)$. In age class III, the lowest variability appeared in the greatest length $(\mathrm{CV}=3.62)$ as in age class II, and the highest in the height of mandible $(\mathrm{CV}=16.96)$. In age class $\mathrm{IV}$, the lowest variability was still present in the greatest length $(\mathrm{CV}=2.96)$, and the nasal length was most variable $(\mathrm{CV}=29.24)$. In age class $\mathrm{V}$, the interorbital breadth was least variable $(\mathrm{CV}=0.39)$, and the highest variability was for the breadth of rostrum $(\mathrm{CV}=21.68)$. In age class VI, the lowest variability occurred again in the greatest length; the highest variability was for the height of mandible $(\mathrm{CV}=18.8)$. The remaining characters concerning respective age classes showed values of $\mathrm{CV}$ lying between the minimum and maximum. Low degrees in variability ( $\mathrm{CV}$ less than 6.00) of the cranial measurements in each age class were found for the greatest length (a range of 2.46-3.98), condylobasal length (2.47-4.06), palatilar length (3.60-4.81), length of mandible (4.49-5.95) and length of lower molar series (4.07-6.46). With the exception of a high value of CV (8.25) in age class II, the zygomatic breadth also had low values of CV (4.11-4.76) in the remaining age classes.

\section{3) Interrelationships among cranial characters}

In order to examine in detail the nature of variation in the field population, one of multivariate statistical methods, principal component analysis (PCA), was utilized. A varimax rotation of factors allowed us to examine more deeply the nature of the variation. Results of the PCA are given in Table 6 with the ten factors accounting for 90 per cent of the total variation. Of these ten factors, the first five factors, with the eigenvalue more than 1.0 and occupying for $66 \%$ of the total variance, were interpreted as follows. Factor 1 loads heavily on three length-related characters of the skull. i.e. the greatest length (0.92), condylobasal length (0.91), basilar length (0.80), and less heavily on the palatilar length (0.53), length of mandible $(0.40)$ and zygomatic breadth (0.30). Factor 2 loads densely on the length of incisive foramen (0.95). Factors 3, 4 and 
Table 6. Results of a principal component analysis on cranial measurements with varimax rotation to simple structure in wild-caught Apodemus semotus.

\begin{tabular}{|c|c|c|c|c|c|c|c|c|c|c|}
\hline \multirow{2}{*}{ Dimension* } & \multicolumn{10}{|c|}{ Principal component } \\
\hline & $\mathrm{PC} 1$ & $\mathrm{PC} 2$ & PC3 & PC4 & PC5 & PC6 & PC7 & PC8 & P C 9 & $\mathrm{PCl0}$ \\
\hline GL & 0.92 & 0.07 & -0.01 & 0.07 & 0.04 & 0.06 & 0.04 & 0.12 & 0.08 & 0.06 \\
\hline $\mathrm{CL}$ & 0.91 & 0.08 & 0.02 & 0.13 & -0.06 & 0.02 & -0.05 & 0.09 & 0.07 & 0.09 \\
\hline $\mathrm{BL}$ & 0.80 & 0.25 & -0.04 & 0.06 & 0.02 & 0.02 & 0.00 & 0.06 & 0.06 & 0.01 \\
\hline PL & 0.53 & 0.16 & 0.14 & 0.17 & 0.14 & 0.02 & -0.01 & 0.03 & 0.05 & 0.00 \\
\hline LIF & 0.21 & 0.95 & 0.03 & 0.07 & 0.10 & 0.08 & -0.04 & 0.00 & -0.01 & -0.03 \\
\hline LUD & 0.16 & 0.06 & 0.06 & 0.97 & 0.00 & 0.01 & -0.01 & 0.02 & 0.00 & -0.02 \\
\hline LUM & 0.01 & 0.10 & 0.14 & 0.00 & 0.96 & 0.09 & 0.06 & 0.13 & 0.02 & -0.08 \\
\hline NL & 0.05 & 0.07 & 0.04 & 0.01 & 0.08 & 0.99 & 0.05 & 0.00 & -0.03 & 0.00 \\
\hline BR & 0.12 & -0.01 & -0.02 & 0.00 & 0.02 & 0.03 & -0.04 & 0.00 & 0.97 & 0.18 \\
\hline IB & 0.16 & 0.00 & 0.05 & 0.02 & 0.12 & 0.00 & -0.01 & 0.98 & -0.01 & -0.02 \\
\hline $\mathrm{ZB}$ & 0.30 & 0.00 & 0.08 & 0.12 & 0.07 & 0.04 & 0.16 & 0.08 & 0.04 & -0.02 \\
\hline BOF & -0.01 & -0.04 & 0.05 & -0.01 & 0.06 & 0.05 & 0.98 & -0.01 & -0.04 & -0.08 \\
\hline LM & 0.40 & 0.25 & 0.16 & 0.12 & 0.17 & 0.15 & -0.05 & 0.08 & 0.06 & -0.01 \\
\hline LLM & 0.00 & 0.03 & 0.97 & 0.06 & 0.13 & 0.04 & 0.05 & 0.05 & -0.03 & -0.10 \\
\hline HM & 0.10 & -0.03 & -0.10 & -0.02 & -0.08 & 0.00 & -0.09 & -0.02 & 0.19 & 0.97 \\
\hline Eigenvalue & 4.65 & 1.90 & 1.22 & 1.12 & 1.03 & 0.97 & 0.82 & 0.72 & 0.58 & 0.53 \\
\hline $\begin{array}{l}\text { Percent of } \\
\text { variance } \\
\text { explained }\end{array}$ & 31 & 13 & 8 & 7 & 7 & 6 & 5 & 5 & 4 & 4 \\
\hline
\end{tabular}

*See text for explanation of abbreviations.

5 load weightily on the length of lower molar series (0.97) and upper diastema (0.97) and upper molar series $(0.96)$, respectively, showing a consequence of tooth replacement processes.

\section{DISCUSSION}

This is the first report on the skull growth and variation of A. semotus. The craniometric characters of a given species are considered to indicate an aspect of the specific status (Koh and Peterson, 1983; Patton and Rogers, 1983; Ando et al., 1989). Thus, our discussion takes the focus on the following three topics.

\section{Analysis of skull growth}

\section{1) Absolute growth}

The largest and second largest growth rates in the first and second periods from day 0 to day 24 were for the nasal length which is obviously related to development of the olfactory structure, i.e. the nasal cavities and particularly the cartilages of the nasal septum (Moore, 1966). In the second period, the palatilar length had the highest value, indicating the consistent growth in the anterior part of the skull. As shown in Table 2, the length-related (an average of $97.7 \%$, excluding the value of condylobasal 
length because of lack of its measurement on day 0), width-related (94.6\%) and mandibular characters $(97.0 \%)$ grew proportionally in the growth rate during the first period, whereas the growth rates of the length-related and mandibular characters slightly exceeded those of the width-related ones in the second and third periods. These findings were in essential agreement with the analysis of skull growth in Rattus norvegicus (Moore, 1966) and Sigmodon fulviventer (Zelditch and Carmichael, 1989).

The most remarkable reduction in growth was for the breadth of occipital foramen ranging from $122.1 \%$ (1st period) to $0 \%$ (3rd period) (Table 2). As to the interorbital constriction, it does not change significantly at all between the 1st and the 39th month of life in Microtus agrestis (Gebczynska, 1964). A. semotus also showed very little growth of the interorbital breadth after day $12(2.1 \%)$, although it grew rapidly before that age $(116.6 \%)$. In rodents, the characteristic specialization is the ability to gnaw, being associated with the structural modification of the jaw musculature, and consequently the deep masseter consists of more vertically orientated fibers arising from the zygomatic arch and being inserted into the lateral surface of the mandible over a wide area (Moore, 1981). Also in A. semotus, the percentage increases of the mandibular measurements were greater in height (a range of 129.6-12.5\%) than in length (64.7-8.0 \%) regarding the respective periods, supporting an adaptation for the gnawing ability of rodents.

It has been said that changes in shape of the skull appear to be closely related to differences in timing of growth in the various cranial dimensions (Moore, 1967). In this connection, there were marked differences in percentage increases of the 15 skull characters among the three growth periods in A. semotus, namely, the length-related characters (the face) and the mandibular characters had the relatively higher growth rates, but the width-related characters (the braincase) were retarded in growth after day 25 when the animals attained almost juvenile size.

\section{2) Relative growth}

The relative growth coefficients in A. semotus ranged from 0.643 to 1.450 (Table 3 ), suggesting the existence of various dimensions showing from a remarkably negative allometry to a positive allometry. According to Tanaka (1942), the skull can be divided into the following three regions: the pre-orbital (nasal length, length of upper diastema, breadth of rostrum and length of incisive foramen), the inter-orbital (length of upper molar series, interorbital breadth and zygomatic breadth), and the post-orbital (breadth of occipital foramen). In A. semotus the relative growth expressed in $\alpha$ was highest in the pre-orbital region (an average of 1.096), intermediate in the inter-orbital region (an average of 0.765 ) and lowest in the post-orbital region (0.648), so that the dead center of the skull resides apparently in the interorbital and occipital parts. It has been noted that the dimensions relevant to the braincase show a markedly negative allometry (Aoki and Tanaka, 1938 for Rattus Zosea; Tanaka, 1942 for A. agrarius; Hiraiwa et al., 1958 for A. speciosus; Nelson and Shump, 1978 for Agouti paca; Ando et al., 1989 for Eothenomys smithii), supporting our results. On the other hand, among the skull dimensions, both the nasal length $(\mathrm{a},=1.450)$ and the height of mandible $(\mathrm{a}=$ 1.387) had a positive allometry against the condylobasal length. 


\section{Analysis of skull variation}

Because patterns of tooth wear in the laboratory-reared specimens vary with ages, tooth classes established on the patterns are suitable to determining relative age classes for many wild-taken specimens of a single population (Adamczewska-Andrzejewska, 1971). As shown in Table 5, A. semotus could be aged accurately by the greatest length with significant subsets which spanned age classes II through VI. The results of principal component analysis (PCA) also indicated that the greatest length had the greatest loading on the first principal component (Table 6), so that it could reflect the closest interrelationship among the skull characters of A. semotus. Conversely, the breadth of occipital foramen was regarded as the most unsuitable indicator because of its negative small value $(-0.01)$ and proved of the lowest relative growth coefficient (0.648) (Table 3).

On the other hand, the greatest length had the lowest coefficients of variation (CV) concerning the respective age classes (Table 5). As pointed out by Cockrum (1954) for Peromyscus leucopus noveboracensis, skull measurements with a low CV do not necessarily vary geographically, or with age or sex in a given age class, and the parameters are suitable for taxonomic purposes. Other characters with a greater loading on the first principal component (condylobasal length, basilar length, palatilar length, length of mandible and zygomatic breadth) had relatively low CV's, suggesting that they were better indicators. The remaining measurements were so variable as to exclude them from future systematic studies, because direct comparisons between populations based on such measurements would be relatively meaningless. In this connection, intrapopulational variability due to individual variation may be greater than interpopulational differences, as pointed out by Robbins (1973) for Taterillus gracilis.

\section{Difference in skull growth between laboratory and field specimens}

Although the corresponding age classes of the field specimens can be determined by patterns of tooth wear in the reared specimens, some factors may affect the skull growth under different conditions, e.g. diets (Ito et al., 1988 for the mouse), photoperiods (Mallory et al., 1986 for Dicrostonyx groenlandicus) and seasonal generations (Kaneko, 1978 for Microtus montebelli), etc., so that direct comparisons between laboratory and field conditions may be open to question. However, at the age when young mice are suckled by their mothers, at least their diets in laboratory and field conditions seem similar in nutrition to each other. In the present study, assessment of differences in the skull growth of $\mathbf{A}$. semotus during the pre-weaning period under the above two conditions was hampered by lack of specimens belonging to age class I (sucklings) in the field. Therefore, the skull measurements used here were chosen from those of specimens in age class II (days 26-35) in both laboratory and field conditions. It is worthy of note that the age when young are weaned and become independent is an important measure when considering patterns of parental investment (Millar et al., 1986).

As given in Table 7, the comparison of skull growth between laboratory and field conditions indicated that the mean values of the palatilar length, length of incisive foramen, length of upper diastema, breadth of rostrum, interorbital breadth, length of mandible and length of lower molar series were significantly different. On the other hand, since the greatest length regarded as the most suitable indicator did not signifi. 
Table 7. Comparison of 15 cranial measurements (Mean \pm SD) in age class II (days 26-35) between laboratory and field conditions in Apodemus semotus.

\begin{tabular}{lccc}
\hline Dimension* & $\begin{array}{c}\text { Laboratory } \\
(\mathrm{n}=7)\end{array}$ & $\begin{array}{c}\text { Field } \\
(\mathrm{n}=13)\end{array}$ & $\begin{array}{c}\text { Significance of } \\
\text { the difference }\end{array}$ \\
\hline GL & $25.25 \pm 0.57$ & $25.41 \pm 1.01$ & $\mathrm{~ns}$ \\
CL & $22.46 \pm 0.56$ & $22.77 \pm 0.92$ & $\mathrm{~ns}$ \\
BL & $18.84 \pm 0.58$ & $18.95 \pm 1.01$ & $\mathrm{~ns}$ \\
PL & $10.15 \pm 0.25$ & $10.91 \pm 0.52$ & $P<0.001$ \\
LIF & $3.78 \pm 0.55$ & $4.98 \pm 0.63$ & $P<0.001$ \\
LUD & $5.67 \pm 0.31$ & $6.77 \pm 0.47$ & $P<0.001$ \\
LUM & $4.06 \pm 0.11$ & $4.29 \pm 0.49$ & $\mathrm{~ns}$ \\
NL & $9.79 \pm 0.61$ & $9.30 \pm 1.10$ & $\mathrm{~ns}$ \\
BR & $3.93 \pm 0.33$ & $4.33 \pm 0.21$ & $P<0.05$ \\
IB & $5.79 \pm 0.69$ & $4.52 \pm 1.20$ & $P<0.01$ \\
ZB & $12.15 \pm 0.10$ & $11.99 \pm 0.99$ & $\mathrm{~ns}$ \\
BOF & $4.83 \pm 0.13$ & $4.46 \pm 1.18$ & $\mathrm{~ns}$ \\
LM & & & \\
LLM & $12.96 \pm 0.47$ & $13.55 \pm 0.81$ & $P<0.05$ \\
HM & $3.12 \pm 0.33$ & $4.28 \pm 0.17$ & $P<0.001$ \\
\end{tabular}

*See text for explanation of abbreviations.

$\mathrm{ns}$, not significant at the 0.05 level by the t-test.

cantly differ, it was proved that age class II established by tooth wear for field specimens was real also from the viewpoint of skull growth, and consequently was concordant with chronological age for laboratory specimens. The measurements of the above characters with significant differences were longer in field specimens than in laboratory ones, except for the interorbital breadth.

Ecological implications of the above difference in skull growth between laboratory and field conditions can be explained as follows. First, the field specimens had a stronger dorsal flexion of the anterior cranial base (longer in the palatilar length, length of incisive foramen, length of upper diastema and breadth of rostrum, and shorter in the interorbital breadth) than did laboratory specimens, meaning the earlier development of the olfactory structure relating to facilitation of finding food and a mate in the field (Cowley, 1980). Second, the lengths of mandible and lower molar series were longer in field specimens than in laboratory ones, suggesting an accommodation for eating solid food much earlier in the field.

From the above consideration, the conclusion can be expressed as follows. The rapid growth of the skull characters in A. semotus occurred on days O-24, especially in bones related to the olfactory structure. After day 25, the width-related characters (the braincase) were retarded in growth, and their dimensions showed a markedly negative allometry. As to the skull variation in field specimens, the greatest length with the lowest coefficients of variation had the greatest loading on the first principal component and was regarded as the most suitable growth indicator. Comparison of the skull growth in age class II (days 26-35) between laboratory and field conditions indicated that the field specimens had a stronger dorsal flexion of the anterior cranial base, and were longer in the lengths of mandible and lower molar series than did the laboratory 
specimens, meaning that the earlier development of the olfactory and mandible structures might be an accommodation for increasing survivals of young mice in the field.

\section{ACKNOWLEDGEMENTS}

We thank Emeritus Professor Teru Aki Uchida of Kyushu University for criticisms during this study and for constructive advice on the earlier draft; Professor E. W. Jameson, Jr., Department of Zoology, University of California for comments on the manuscript. We are also indebted to graduate students of our laboratory and Biology Department, Tunghai University, for their kind assistance in preparation for skull samples.

\section{REFERENCES}

Adamczewska-Andrzejewska, K. 1971 Methods of age determination in Apodemus agrarius. Ann. Zool. Fennici, 8: 68-71

Adamczewska-Andrzejewska, K. 1973 Growth, variation and criteria in Apodemus agrarius, Acta Theriol., 18/19: 353-394

Ando, A., S. Shiraishi, N, Higashibara and T. A. Uchida 1989 Relative growth of the skull in the laboratory-reared Smith's red-backed vole, Eothenomys smithii and so-called "Kage" red-backed vole, E. kageus. J. Fac. Agr., Kyushu U niv., 33: 297-304

Aoki, B. and R. Tanaka 1938 Biostatistical research on Rattus losea, a Formosan wild rat, with special reference to its diagnostic characters for taxonomy. Mem.Fac. Sci. Agr. Taihoku Imp. Univ. Formosa, Japan, 13: 1-74

Cockrum, E. L. 1954 Nongeographic variation in cranial measurements of wild-taken Peromyscus leucopus noveboracensis. J. M amm., 35: 367-376

Cowley, J. J. 1980 Growth and maturation in mice (Musmusculus).Symp.zool.Soc. Lond., 45: 213250

Delany, M. J. 1970 Variation and ecology of island populations of the long-tailed field mouse (A podemus sylvaticus).Symp.zool.Soc. Lond., 26: 283-295

Delany, M. J. and P. E. Davis 1961 Observations on the ecology and life history of the Fair Isle field mouse, Apodemus sylvaticus fridariensis (Kinnear). Proc.zool.Soc. Lond., 136: 439-452

Fujimaki, Y. 1966 Age variations in the external characters of Apodemus argenteus.Mem.Fac. Agr., Hokkaido U niv., 5: 212-217 (in Japanese with English abstract)

Gebczynska, Z. 1964 Morphological changes occurring in laboratory Microtusagrestis with age. Acta Theriol., 4: 67-80

Gurnell, J. and C. I. Knee 1984 Determining the age of wood mice (A podemus sylvaticus). Folia Zool., 33: 339-348

Haitlinger, R. 1962 Morphological variability in Apodemus agrarius(Pallas 1771). Acta Theriol., 6: 239-256

Haitlinger, R. 1969 Morphological variability of the Wroclaw population of Apodemus sylvaticus (Linnaeus, 1758). Acta Theriol., 14: 285-302

Hiraiwa, Y. K., M. Tokuda, T. Uchida and H. Sugiyama 1958 Some small mammals from the Islands of $\mathrm{Oki}$, with especial reference to detail examination of their subspecific characteristics. Sci. Bull. Fac.Agri.,Kyushu Univ., 16: 547-574 (in Japanese with English résumé)

Imaizumi, Y. 1962 On the species formation of the Apodemus speciosus group, with special reference to the importance of relative values in classification. Bull. Nat. Sci. Mus., 5: 163-259

Ito, G., S. Mitani and J. H. Kim 1988 Effect of soft diets on craniofacial growth in mice. Anat. Anz., Jena, 165: 151-166 
Kaneko, Y. 1978 Seasonal and sexual differences in absolute and relative growth in Microtus montebelli. Acta Theriol., 23: 75-98

Koh, H. S. and R. L. Peterson 1983 Systematic studies of deer mice, Peromyscus maniculatus Wagner (Cricetidae, Rodentia): analysis of age and secondary sexual variation in morphometric characters. Can. J.Zool., 61: 2618-2628

Lin. L. -K., T. Nishino and S. Shiraishi 1993 Postnatal growth and development of the Formosan wood mouse Apodemus semotus. J. Mamm. Soc., Japan, 18 (in press)

Mallory, F. F., R. J. Brooks and J. R. Elliott 1986 Variations of skull-body regressions of the lemming (Dicrostonyx groenlandicus) under laboratory and field conditions. Zool. J. Linn. Soc., 87: $125-188$

Manly, B. F. 1986 Multivariate Statistical Methods. Chapman and Hall, London

Matson, J. 0. and K. A. Shump, Jr. 1980 Intrapopulation variation in cranial morphology in the agouti, Dasyprocta punctata (Dasyproctidae). Mammalia, 44: 559-570

Millar, J. S., D. A. L. Burkholder and T. L. Lang 1986 Estimating age at independence in small mammals. Can. J.Zool., 64: 910-913

Miyao, T. and T. Mōri 1968 Studies on the geographical variation of the small mammals in Japanese Islands. III. Geographical variation of body sizes in Apodemus argenteus. J. Growth, 7: 1-8 (in Japanese with English summary)

Miyao, T., T. Mōri and T. Morozumi 1968 Studies on Apodemus speciosus from the island of Oki. Honyurui Kagaku (Mammalian Science), (16): 37-51 (in Japanese with English summary)

Moore, W. J. 1966 Skull growth in the albino rat (Rattus norvegicus).J.Zool., Lond., 149: 137-144

Moore, W. J. 1967 Muscular function and skull growth in the laboratory rat (Rattus norvegicus). $J$. Zool., Lond., 152: 287-296

Moore, W. J. 1981 The Mammalian Skull. Cambridge University Press, London

Nelson, T. W. and K. A. Shump, Jr. 1978 Cranial variation and size allometry in Agouti paca from Ecuador. J. Mamm., 59: 387-394

Patton, J. L. and M. A. Rogers 1983 Systematic implications of non-geographic variation in the spiny rat genus Proechimys (Echimyidae). Z. Säugetierk., 48: 363-370

Robbins, C. B. 1973 Nongeographic variation in Taterillus gracilis (Rodentia: Cricetidae). J. Mamm., 54: 222-238

Sikorski, M. D. 1982 Craniometric variation of Apodemus agrarius (Pallus, 1771) in urban green areas. ActaTheriol., 27: 71-81

Simpson, G. G., A. Roe and R. C. Lewontin 1960 Q uantitative Zoology. Harcourt, Brace and World, Inc., New York

Tanaka, R. 1942 A biostatistical analysis of Apodemus agrarius from Formosa with special reference to its systematic characters. Mem. Fac. Sci. Agr. Taihoku Imp. Univ. Formosa, Japan, 23: 212-285

Yoshida, H. 1983 A note on the morphology of Apodemus speciosus collected in the mountain districts in Kyushu. Biologia Fukuokana, (23): 19-24 (in Japanese)

Yoshida, H. 1984 A note on the morphology of Apodemus argenteus collected in the mountain districts in Kyushu. Biologia Fukuokana, (24): 22-27 (in Japanese)

Zelditch, M. L. and A. C. Carmichael 1989 Growth and intensity of integration through postnatal growth in the skull of Sigmodon fulviventer. J. Mamm., 70: 477-484 